\title{
TENDER OFFERS IN THE BROADCAST INDUSTRY
}

\section{INTRODUCTION}

Although many view mass media as an important means of conveying a diversity of opinions, ideas, and information to the public, ${ }^{1}$ former Federal Commurications Commission (FCC) Chairman Mark Fowler rejected the notion that broadcasting is a unique industry. He characterized the television as "just another appliance, . . . a toaster with pictures." 2 Fowler thus advocated unrestricted operation of the free market in the broadcast industry. ${ }^{3}$ In 1985 , the broadcast industry experienced unprecedented merger and acquisition activity. ${ }^{4}$ In contrast to transfers of control in unregulated businesses, all transfers of control involving broadcast licenses must be exammed and approved by the FCC. The Commission feared that its traditional approval procedures-which strictly control corporate broadcast licensees-would inhibit the free market.

The Communications Act of 1934,5 designed to control the "allocation and regulation of the use of radio frequencies by prohibiting such use except under license," 6 gives the FCC the responsibility of granting applications for broadcast licenses on the basis of whether the grant will serve "the public interest, convenience and necessity."7 The public interest standard is not an unlimited directive to further the general public welfare. Rather, the purposes behind the Communications Act reveal that the public's interest with respect to broadcasting lies in receiving high-quality service from a qualified licensee. ${ }^{8}$

1. See, e.g., Compaigne, The Expanding Base of Media Competition, J. Comm., Summer 1985, at 81 .

2. Mayer, FCC Chief's Fears: Fowler Sees Threat in Regulation, Wash. Post, Feb. 6, 1983, at K6, col. 1.

3. See Fowler \& Brenner, A Marketplace Approach to Broadcast Regulation, 60 TEX. L. REV. 207 (1982).

4. See, e.g., Heightened Prospects for Radio-TV Acquisitions, MERgers \& ACQUisitions, Spring 1985, at 47; Sherman, Are Media Mergers Smart Business?, ForTUNE, June 24, 1985, at 98; Merger Mania Mounts, AdVertising AGE, Apr. 15, 1985, at 1; The New Bonanza in Broadcasting, Broadcasting, Apr. 15, 1985, at 43; Hall, Media Madness, Financial World, April 17-30, 1985, at 12.

5. Communications Act of 1934, ch. 652,48 Stat. 1064 (codified as amended at 47 U.S.C. $\S \S 151-613(1988))$.

6. FCC v. Sanders Bros. Radio Station, 309 U.S. 470, 474 (1940).

7. 47 U.S.C. $\$ 309$ (a) (1988).

8. One Two Corp., 58 Rad. Reg. 2d (P \& F) 924, 941 (1985) (Quello, Comm'r, dissenting). 
The Communications Act imposes procedural requirements on the application review process in order to ensure that FCC licensing decisions are based on appropriate public interest determinations. These requirements include allowing for public comment and submission of petitions to deny the application. In the event of such petitions, the applicant is permitted to reply. Depending upon whether a substantial question of material fact as to the applicant's qualifications is raised, the FCC may schedule a hearing. Only after this process can the Commission decide whether granting the application will serve the public interest. This procedure generally apphes to those seeking a broadcast license, as well as those, such as tender offerors, seeking to gam control of a licensee. Therefore, before a tender offer of a broadcast coinpany can be consummated, the tender offeror must apply to the FCC, the public must be allowed time to submit comments and petitions to deny the application, and ultimately the Commission must determine that a transfer of control to the applicant is in the public interest.

Section 309(f), the focus of this Note, provides an exception to this procedural scheme. That provision authorizes the Commission to grant special temporary operating authority (STA), which bypasses the traditional review procedures including the public comment period, "if [the Commission] finds that there are extraordinary circumstances requiring temporary operations in the public interest and that delay in the institution of such teinporary operations would seriously prejudice the public interest." This Note addresses the Commission's use of that exception in the context of tender offers involving broadcast licenses.

The Commission detailed the apparent inadequacies of the traditional approval procedures in its Notice of Inquiry on Tender Offers and Proxy Contests. ${ }^{10}$ The inquiry solicited comments concerning appropriate agency procedures to be used in connection with tender offers. The Commission sought a new procedure that would achieve four objectives. The first objective, a procedural one, was compliance with the requirements of the Communications Act. The other three objectives were policy goals designed to promote government neutrality, avoid unnecessary delays, and accommodate other laws concerning the governance of corporations.

Although the FCC labelled compliance with the procedural requirements of the Communications Act an objective, such compliance is not a discretionary option-it is a mandate. Only if the new procedure advocated by the Commission complies with the Act is it legal. And even if

9. 47 U.S.C. $\$ 309(f)$ (1988).

10. Tender Offers and Proxy Contests, Notice of Inquiry, MM Docket No. 85-218, FCC 83-349 (adopted July 9, 1985; released August 20, 1985). 
the new procedure satisfies this obstacle, it must still comply with the Act's poticy mandate of furthering the public interest.

This Note examines the Commission's determination, set forth in its Policy Statement on Tender Offers and Proxy Contests, ${ }^{11}$ that tender offers warrant treatment under section 309(f) and concludes that this utilization of section 309(f) violates the procedural and policy mandates of the Communications Act. After discussing the procedure adopted by the Commission, ${ }^{12}$ the Note, through an analysis of the language of the Communications Act, ${ }^{13}$ its legislative history, ${ }^{14}$ and the Coinmission's applications, ${ }^{15}$ demonstrates that the Commission exceeded its authority by adopting such a procedure. Finally, the Note examines the policies that the Commission sought to serve through the new procedure and concludes that not only are the premises upon which the goals are based misleading, but also that the goals themselves are incompatible with the policy objective underlying the Communications Act of serving the public interest. ${ }^{16}$

\section{Procedural Mandates}

The primary responsibility of the Federal Comınunications Coinmission is to execute and enforce the provisions of the Communications Act. ${ }^{17}$ Those provisions prohibit the unlicensed use of the airwaves ${ }^{18}$ and empower the FCC to grant applications for new broadcast licenses, for modification or renewal of broadcast licenses, and for transfers of licenses or companies holding broadcast licenses. ${ }^{19}$ Therefore, before consummation of a tender offer involving a company holding an FCC license, the offeror must secure Commission approval. Such approval depends upon

11. Tender Offers and Proxy Contests, 59 Rad. Reg. 2d (P \& F) 1536 (1986) [hereinafter Policy Statement].

12. See infra notes $27-52$ and accompanying text.

13. See infra notes 53-63 and accompanying text.

14. See infra notes $64-92$ and accompanying text.

15. See infra notes $93-112$ and accompanying text.

16. See infra notes $113-68$ and accompanying text.

17. 47 U.S.C. $\S 151$ (1988).

18. Id. $\S 301$.

19. Section 308 gives the Commission the authority to grant "station licenses, or modifications or renewals thereof." Id. $\S 308($ a). Pursuant to section 310(d), the Commission is authorized to grant applications for transfers of control of broadcast licenses. In each situation, the same procedures govern:

No... station license, or any rights thereunder, shall be transferred, assigned, or disposed of in any manner, voluntarily or involuntarily, directly or indirectly, or by transfer of control of any corporation holding such ... license, to any person except upon applieation to the Commission.... Any such application shall be disposed of as if the proposed transferee or assignee were making application under section 308 of this title for the ... license in question ....

Id. $\S 310$ (d). 
a determination by the Commission that the "public interest, convenience, and necessity would be served by the granting"20 of the license application.

\section{A. The Statute's Application Approval Requirements}

Approval by the FCC traditionally involves the following procedural requirements. The applicant seeking consent to a transfer of control must file a long form application. ${ }^{21}$ After public notice of the hicense application, section 309(b) of the Act imposes a thirty-day waiting period for public comment.22 This waiting period is meant to ensure that the public has an opportunity to participate in the Commission's public imterest determination. Petitions to deny the application may be filed, in which case an applicant is given additional time to file a reply. ${ }^{23}$ If the Commission determines that a substantial and material question of fact exists as to whether the public interest, convenience, and necessity will be served by granting the application, the Commission will designate the application for hearing. ${ }^{24}$

Section 309(f) of the Commumications Act authorizes the Commission to bypass the traditional procedures for granting license applications. The Commission may grant a special temporary authority (STA) to broadcast immediately "if it finds that there are extraordinary circumstances requiring temporary operations in the public interest and that

\footnotetext{
20. Section 309(a) provides:

[T] he Commission shall determine, in the case of each application filed with it to which section 308 of this title applies, whether the public interest, convenience, and necessity will be served by the granting of such application, and, if the Commission, ... . upon consideration of such other matters as the Commission may officially notice, shall find that public interest, convenience, and necessity would be served by the granting thereof, it shall grant such application.
}

Id. $\S 309$ (a).

21. Pursuant to 47 C.F.R. $\$ 73.3540$ (d) (1989) applications for consent to transfer of control of corporations holding broadcast licenses must be filed on FCC Form 315-a long form applicationor FCC Form 316, a short form application. "Generally, a short form application . . . is used in situations described in Section 309(c)(2)(B) of the Act, including those that do not involve a substantial change in ownership or control. In other situations, the long form application . . . is normally used." One Two Corp., 58 Rad. Reg. 2d (P \& F) 924, 925 n.1 (1985) (citations omitted).

22. "Except as provided in subsection (c) of this section, no such application . . shall be granted by the Commission earlier than thirty days following issuance of public notice by the Commission of the acceptance for filing of such application or of any substantial amendment thereof." 47 U.S.C. $\S 309$ (b) (1988).

23. "Any party in interest may file with the Commission a petition to deny any application ... to which subsection (b) of this section applies at any time prior to the day of Commission grant .... The applicant shall be given the opportunity to file a reply . . . " Id. $\S 309$ (d)(1).

24. "If, in the case of any application to which subsection (a) of this section applies, a substantial and material question of fact is presented or the Commission for any reason is unable to make the finding specified in such subsection, it shall formally designate the application for hearing ...." Id. $\S 309(\mathrm{e})$. 
delay in the institution of such temporary operations would seriously prejudice the public interest." 25 That temporary grant is limited to 180 days, with the possibility of an unlimited number of 180-day extensions. ${ }^{26}$

\section{B. The Commission's Bifurcated Procedure}

In 1985 the Coinmission, relying on section 309(f), began employing a bifurcated procedure for the approval of tender offers involving FCC licenses. ${ }^{27}$ This approach utilizes an interim voting trust as a supplement to the traditional license application and was adopted in the Commission's Policy Statement. Under this two-step procedure, the offeror sinultaneously submits a traditional long form application, a short form application, ${ }^{28}$ and a trust agreement. On an expedited basis, without awaiting section 309(b)'s 30-day petition to deny period, the Commission reviews only the short-form application and the trust agreement. In the trust agreement, the tender offeror subinits an independent trustee. The Comimission will assess the qualifications of the tender offeror's chosen trustee to determine whether he slould be permitted to collect and vote the sliares of stock tendered in response to the offeror's bid and to operate the licensed facility, if enough shares are collected. ${ }^{29}$ If the short-form application is approved, the Commission grants a section 309(f) STA to the trustee. Subject to certain conditions, the trustee can exercise the rights of operation, collection, and voting. These conditions include, for example, the requirement of strict separation between the trustee and the offeror to ensure that the trustee will be able to act independently. ${ }^{30}$ If the tender offer is successful, the second step entails consideration of the long form application of the tender offeror for transfer

\section{Id. $\S 309(\mathrm{f})$.}

26. Id.

27. The first decision in which the FCC approved the two-step procedure for tender offers, One Two Corp., 58 Rad. Reg. 2d (P \& F) 924 (1985), was released on July 19, 1985. The Commission had endorsed the procedure in Tender Offers and Proxy Contests, Notice of Inquiry, supra note 10, which was adopted on July 9, 1985, but not released until August 20, 1985.

28. See supra note 21 for discussion of long-form and short-form applications. The use of short-form applications in the Policy Statement's bifurcated procedure is based solely on section 309(f), not on a finding that tender offers constitute insubstantial changes in control. See Policy Statement, supra note 11, at 1569 n.147.

29. Policy Statement, supra note 11, at 1562-63.

30. Id. at 1579 ("The best method of safeguarding the independence of the trustee is to require strict separation between the trustee and the offeror."). Although significant restrictions are imposed on the trustee, he or she also retains substantial authority. "The trustee will be permitted, for example, to participate in the election of the Board of Directors. The trustee may elect to serve as a director personally and may fully vote the tendered stock in corporate elections of the Board." Id. at 1582 (footnote omitted). 
of control from the trustee. ${ }^{31}$ The second step includes review of any petitions to deny, rephes, or hearings that would otherwise accompany license grants under section 309(b).

The Coinmission asserts that its reliance on section 309(f) in departing froin the procedures required by section 309(b) complies with the inandates of the Coinmurnications Act. ${ }^{32}$ The Policy Statement emphasizes that the Commission has the discretion to consider the grant of STA's with respect to all categories of applications, including situations that involve ownership changes. ${ }^{33}$ As the Agency noted, "[t]he purpose of [the provision] was to enable the Commission to avoid the statute's 30day waiting period in appropriate circumstances, [and there is no basis] for believing this purpose does not apply to the 30-day period for transfer applications." ${ }^{34}$ After estabhishing the appropriateness of section 309(f)'s apphication in the tender offer context, the Commission deterinined that tender offers categorically satisfy the provision's requireinents.

The fundamental requirement of section 309(f) is that "extraordinary circuinstances" exist before the departure from traditional hicense approval procedures is justified. According to the Coinmission, hostile tender offers themselves are "extraordinary circumstances" within the ineaning of the statute. ${ }^{35}$ The Policy Statement offers three justifications in support of this conclusion. First, the Commission noted that tender offers may be subject not only to the procedural requirements of the Communications Act and the rules of the Commission, but also to the Williams Act, ${ }^{36}$ SEC rules implementing that Act, and state regulations. The Commission concluded that the potential for conflicts among regulatory schemes presents an extraordinary circumstance meriting section 309(f) special procedures. ${ }^{37}$ One potential conflict results from the Williains Act's provision for withdrawal of tendered shares by the shareholders if a tender offer is not consummated within sixty days. ${ }^{38}$ In the broadcast industry, this provision can work hardship on tender offerors

31. Id. at 1563-64.

32. "We find [that the] . . . criteria [of section 309(f)] are met in the exceptional situation in which a tender offer is used as a means to obtain control of a communications corporation." Id. at 1570.

33. Id. at 1573.

34. Id. at 1573 n.165 (quoting L.P. Media, Inc., 58 Rad. Reg. 2d (P \& F) 1527, 1530 (1985)).

35. Id. at 1570 ("[I]t is the circumstances presented by the tender offer itself that are extraordinary" (quoting L.P. Media, 58 Rad. Reg. 2d (P \& F) at 1532)).

36. The Williams Act, Pub. L. No. 90-439, 82 Stat. 454 (1968) (codified as amended at 15 U.S.C. $\S \S 78 \mathrm{~m}(\mathrm{~d})$-(e), $78 \mathrm{n}(\mathrm{d})$-(f) (1988)), added sections 13(d), 13(e), 14(d), 14(e), and 14(f) to the Securities Exchange Act of 1934.

37. Policy Statement, supra note 11, at 1569.

38. 15 U.S.C. $§ 78 \mathrm{n}(d)(5)$ (1988); see infra text accompanying notes 145-148. 
who would consummate their offers within sixty days but for the waiting periods incorporated into traditional Commission approval. Thus, the combination of the Williams Act and the Communications Act may restrict the ability of tender offerors to provide to shareholders the financial opportunities normally available in the marketplace. ${ }^{39}$ Without the use of expedited procedures, the Commission sees its regulatory processes as effectively precluding the use of tender offers to obtain control over communications compamies.

Not only do tender offerors in the broadcast field face potentially conflictimg regulatory schemes, but those schemes also are aimed at the achievement of varymg policy goals. The second rationale offered in the Policy Statement to demonstrate that tender offers involving broadcast companies constitute "extraordinary circumstances" is the compelling need to accommodate the public policies embodied in security laws on tender offers. ${ }^{40}$ The main policy objective of the Williams Act, for instance, is shareholder protection. As a necessary incident of that objective, the Williams Act encourages strict neutrahty on the part of the SEC. ${ }^{41}$ The FCC sees the delays inherent in the use of long-form procedures for tender offer applications as biased toward incumbent management, and thus as inconsistent with the goal of neutrality. ${ }^{42}$

Finally, the extraordinary circumstances that conmunications industry tender offers present include the potential use of administrative procedures as a shield by incumbent management. ${ }^{43}$

Having determined that tender offers involving broadcast licensees are "extraordinary," the Commission asserts that the temporary "operations" authorized by section 309(f) do not refer simply to temporarily permitting the broadcasting of signals when traditional application procedures would result in a threat to signal transmission. Instead, the Commission argues that the term "operations" refers to temporarily changing ownership of a licensee where no threat to sigual transinission is present. In the FCC's view, transferring control of a licensed company to a trustee constitutes "temporary operations." 44

39. Policy Statement, supra note 11 , at 1570.

40. Id. at 1571 .

41. Piper v. Chris-Craft 1ndus., 430 U.S. 1, 30 (1977) (achieving government neutrality was not the objective of the Act, but is a necessary characteristic of legislation with the purpose of protecting shareholder interests).

42. For discussion of FCC's argument that delays inherent in the long form procedures unduly favor management, see infra notes 143-149 and accompanying text.

43. Policy Statement, supra note 11, at 1571. For discussion of the potential for incumbent management to use the traditional procedures as a shield, see infra notes 148-149 and accompanying text. This argument is really a subset of the FCC's argument that long form review procedures unduly favor management.

44. Id. at 1571-72. 
The legality of this bifurcated procedure approved by the Commission in the Policy Statement has not been judicially determined. ${ }^{45}$ Skepticism exists within the Commission itself, ${ }^{46}$ on the bench, ${ }^{47}$ and among legal scholars ${ }^{48}$ as to wliether the Commission has accurately interpreted section 309(f).

\section{Statutory Construction}

When a federal court rules on the merits of a challenge to the legality of the procedures adopted in the Policy Statement, it will not be bound by the Commission's construction of the Commumications Act. As the Supreme Court explained, "[t]he judiciary is the final authority on the issue of statutory construction and must reject administrative constructions which are contrary to clear congressional intent." 49 Using the "traditional tools of statutory construction,"50 the court.reviewing the FCC's bifurcated procedure must examine congressional intent regarding the application of section 309(f)'s special temporary authority. In analyzing congressional intent, the court is "not required to grant any particular deference to the agency's parsing of statutory language or its interpretation of legislative history." 51 Only if the court determines that the intent of Congress as to when STA's may be granted is unclear from the language and legislative history of the Act, will the court proceed to determme whetler the agency's interpretation is valid as based on "a permissible construction of the statute."52 The Court reacles this second step of determining whether the agency's interpretation is reasonable

45. Review of Policy Statement was sought in Office of Communication of United Church of Christ v. F.C.C., 826 F.2d 101, 103 (D.C. Cir. 1987). However, the majority dismissed the suit as not sufficiently ripe for judicial consideration.

46. Commissioner Quello dissented from Policy Statement, stating that he "reject[s] the idea that employing a trustee arrangement in the hostile takeover context can substitute for full examination of the applicant's qualifications before a substantial change in ownership or control of a licensee can be approved." Policy Statement, supra note 11, at 1584 (Quello, Comm'r, dissenting).

47. See, e.g., United Church, 826 F.2d at 113 n.6 (Wald, J., dissenting) ("Were the panel to reach the merits, I would hold that the FCC's new policy with respect to tender offerors goes beyond its statutory power under $\S 309$ (f).").

48. See, e.g., McGill, The Market For Corporate Control in the Broadcasting Industry, 40 FED. CoMm. L.J. 39, 75 (1988) ("conditional approval represented by the STA may strain the Commission's statutory directive").

49. Chevron U.S.A., Inc. v. NRDC, 467 U.S. 837, 843 n.9 (1984); see Note, Redefining "Common Carrier": The FCC's Attempt at Deregulation by Redefinition, 1987 DukE L.J. 501, 514-19 (discussing judicial review of the FCC's interpretation of the Communications Act in compliance with the Supreme Court's decision in Chevron).

50. Chevron, 467 U.S. at 843 n.9; see also I.N.S. v. Cardoza Fonseca, 480 U.S. 421, 432 (1987) (discussing use of legislative history in determining congressional intent).

51. Transbrasil S.A. Linhas Aereas v. Department of Transp., 791 F.2d 202, 205 (D.C. Cir. 1986) (quoting Rettig v. Pension Benefit Guar. Corp., 744 F.2d 133, 141 (D.C. Cir. 1984)).

52. Cherron, 467 U.S. at 866. 
only if it finds that the first step is not satisfied, that is, only if Congress was not clear. The second step is not necessary in this case because an analysis of the language of the Communications Act and its legislative history unequivocally demonstrate that Congress did not intend for the special procedures of section 309(f) to apply categorically to tender offers.

1. Language of the Statute. The original source that courts must consult when determining congressional intent is the language of the statute. ${ }^{53}$ STA's are available to all qualifying applicants, whether they seek new broadcast licenses, renewals or modifications of existing licenses, or transfers of ownership or control of broadcast licensees. ${ }^{54}$ No question exists about the Act's meaning on that point. ${ }^{55}$ The real debate surrounds not the scope of the provision's applicability, but rather the requirements that must be satisfied for an STA to be granted.

The Communications Act does not define the terms "extraordinary circumstances" or "operations." 56 The plain meaning of the language, however, is ordinarily regarded as conclusive in the absence of "a clearly expressed legislative intention to the contrary." 57 The language of section 309(f) reveals that the requisite "extraordinary" conditions will be met only where temporary authorization is necessary to "institute" immediate broadcast "operations" or to prevent their discontinuance. ${ }^{58}$ Contrary to the Commission's assertion that change of ownership of a licensee constitutes operations, the focus of the provision is on station operations-the transmitting of broadcast signals-and not on the identity of the operator. Granting an STA pursuant to the procedure adopted in the Policy Statement only affects the identity of who controls the operations, not whether the operations themselves will continue.

53. See Watt v. Alaska, 451 U.S. 259, 265 (1981) ("The starting point in every case involving statutory construction of a statute is the language itself." (quoting Blue Chip Stamps v. Manor Drug Stores, 421 U.S. 723, 756 (1975) (Powell, J., concurring))); Consumer Prod. Safety Comm'n v. GTE Sylvania, Inc., 447 U.S. 102, 108 (1980) ("We begin with the familiar canon of statutory construction that the starting point for interpreting a statute is the language of the statute itself.").

54. All applicants subject to section 309(b) are eligible for a 309(f) STA. 47 U.S.C. $\$$ 309(f) (1988). Section 309(b) sets forth the general application procedure for applications "to which section 308 ... applies." Id. $§ 309$ (a). According to section 310(d), applications for transfers of control are to "be disposed of as if the proposed transferee . . . were making application under section 308 ..." Id. $\$ 310($ d). Applications for transfers of control, therefore, are eligible for grants of STA's under section 309(f).

55. For a discussion of the FCC's emphasis on its discretion to grant STA's with respect to all categories of applicants, see supra text accompanying notes 33-34.

56. See 47 U.S.C. $\$ 153$ (1988).

57. Consumer, 447 U.S. at 108.

58. See 47 U.S.C. $\S 309(f)$ (1988). 
Operations that are ongoing and not faced with the possibility of interruption, as in the case of the typical tender offer, are not in need of special temporary authorization to assure the "institution of operations." Admittedly, a tender offer can arise under circumstances that, irrespective of the offer, satisfy the requirements of section 309(f). ${ }^{59}$ The Commission, however, based its approval of granting STA's in the tender offer context on the characteristics of broadcast industry tender offers themselves.

Finally, the Commission's assertion in the Policy Statement that all tender offers categorically meet the requirements of section $309(\mathrm{f})^{60}$ is contrary to the language of the provision. This provision specifically calls for findings by the Commission and a statement of reasons why a temporary authority is necessary in each case in which an STA is granted. ${ }^{61}$ Plainly, this extraordinary procedure was not intended to be the routine practice for dealing with tender offers. This conclusion is supported by section 310 (d), which specifically addresses applications for involuntary transfers of control of corporations holding station licenses. In that section, Congress did not instruct the Commission to employ the special procedures of section 309(f) when dealing with hostile tender offers, but instead directed the Commission to conduct the standard review of the transfer application just as if the proposed transferee were making application for the license in question. ${ }^{62}$

An evaluation of the plain meaning of section 309(f) suggests that it should not apply categorically to tender offers. Because the Communications Act supplies no express definitions for the key terms in section 309(f), however, a reviewing court likely will undertake further statutory analysis to ensure that this plain meaning interpretation was the clear

59. For example, if the tower of a community's only radio broadcaster was destroyed, the company holding the license to broadcast from that tower could apply for an STA to broadcast at variance from its license from a distant tower. The Commission could grant the STA in full compliance with the Communications Act because extraordinary circumstances-the potential absence of any available programming in the community-required temporarily transmitting the broadcast signal from a different tower. If the company holding the license could not afford to move temporarily to the distant tower, but a tender offeror sought to take control of the company and to relocate broadcasting for a short time, the Commission could again grant the STA in full compliance with the Act because the requirements of section 309(f) were satisfied irrespective of the offer. See also Gale Broadcasting Co., 15 Rad. Reg. 2d (P \& F) 337 (1969).

60. The Commission stated that,"Section 309(f) empowers us to grant an STA to a trustee in all situations involving a tender offer of a communications company." Policy Statement, supra note 11 , at $1569 \mathrm{n} .147$ (emphasis added).

61. 47 U.S.C. $\S 309$ (f) (1988).

62. See supra note 19. 
intention of the Congress. Further statutory analysis entails an examination of the Communication Act's legislative history. ${ }^{63}$

2. Legislative History. Neither section $309(f)$ as originally enacted nor as amended was intended to apply categorically to tender offers.

a. Post-grant protest procedures. Congress enacted section 309(f) of the Coninuunications Act in 1960 as part of a drastic restructuring of the FCC's hicensing procedures. ${ }^{64}$ Prior to the 1960 amendments, public objections to a license application were considered by the Commission only after the Commission had reviewed and granted the application. ${ }^{65}$ If, as a result of such protests, the Coninission deenied an evidentiary hearing necessary, the FCC was authorized to allow the licensee to continue interim operations of its facility upon a finding that "the public niterest requires that the grant reniain in effect." 66

b. Pre-grant protest procedures. Prenised on the congressional conclusion that "it is more satisfactory that substantial objections to an application be considered before rather than after a grant," 67 the new pre-grant protest procedures of section 309 (b) ${ }^{68}$ were nieant to ensure protesting parties that their objections would be given "timely and adequate consideration." 69 In the event that a substantial and niaterial question of fact is presented and not resolved, the statute niakes it "absolutely clear that the application will be designated for hearing before" being granted. ${ }^{70}$ Section 309 (f) represents an exception to this general policy of denying the use of the airwaves by those whose public interest qualifications have not been established.

63. See Washington Hosp. Center v. Bowen, 795 F.2d 139, 143 (D.C. Cir. 1986) ("inquiry into congressional intent encompasses both statutory language and legislative history"); Donovan v. Rose Law Firm, 768 F.2d 964, 970 (8th Cir. 1985) (if congressional intent is not plainly indicated by statutory language court should turn to legislative history). There are disputes over the degree to which the court should emphasize legislative history. See Note, Justice Scalia's Use of Sources in Statutory and Constitutional Interpretation: How Congress Always Loses, 1990 DUKE L.J. 160, 16165.

64. Communications Act Amendments of 1960, Pub L. No. 86-752, 74 Stat. 889 (codified in scattered sections of 47 U.S.C. (1988)).

65. Communications Act Amendments of 1952, Pub. L. No. 82-554, § 309(b), 66 Stat. 711 (codified at 47 U.S.C. $\$ 309$ (1988)); see Folkways Broadcasting Co., v. F.C.C., 379 F.2d 447, 449 (D.C. Cir. 1967) (describing post-grant protest procedures).

66. Act of Jan. 20, 1956, Pub. L. No. 84-391, § 309(c), 70 Stat. 3.

67. S. REP. No. 690,86 th Cong., 1st Sess. 2 (1959).

68. See supra notes $20-24$ and accompanying text.

69. S. REP. No. 690 , 86th Cong., 1st Sess. 2 (1959).

70. H.R. REP. No. 1800, 86th Cong., 2d Sess. 12 (1960) (emphasis added). 
c. The 1960 version of section $309(f)$. Section 309(f), as enacted in 1960, gave the Commission the authority to grant temporary operating authorization, acconipanied by a statement of its reasons, "if it finds that there are extraordinary circumstances requiring emergency operations in the public interest and that delay in the institution of such eniergency operations would seriously prejudice the public interest."71 The grant of eniergency operations was limited to ninety days, with the possibility of one additional ninety day period upon certain findings by the Commission. ${ }^{72}$ Although the legislation did not supply examples of situations that satisfied the provision's requirements, Congress did offer examples of situations that would fail only the section's "emergency" requirement. Situations not properly qualifying as emergencies included "requests for service to a broadcaster for renıte pick-ups of special events, inauguration of network service to a new broadcast station or requests for the establisliment of service to new and temporary headquarters of the President."73

The situations above were inappropriate for STA grants solely due to the lack of urgency, not because they failed to constitute "operations." Thus, contrary to the FCC's assertion in the Policy Statement, the reference to "operations" in the statute was intended to refer to the necessity of having broadcast signals transmitted-the need for "service"-not to the necessity of having a certain operator control the transmission of those signals. Tender offers generally affect only the choice of who operates a broadcast facility, not whether or not it functions.

Congress' belief that section 309(f) would rarely be invoked reveals that the provision was intended to be a narrow exception. The provision was to serve as a "safety valve to protect the public interest in those rare cases in which the Commission finds that the delay required by [the pregrant protest procedures] would seriously prejudice the public interest." 74 The mtended limited use of section 309(f) is exemplified by the process by which it was introduced into the bill.

The Federal Conımunications Bar Association ("FCBA"), which requested the introduction of the original bill modifying the existing post-grant public protest procedures, ${ }^{75}$ did not include a provision for teniporary authorizations in its request. Instead, the FCC brought up the possibility that extraordinary circumstances might require emergency

71. Communications Act Amendments, 1960, Pub. L. No. 86-752, § 309(f), 74 Stat. 889, 891.

72. Id.

73. S. Rep. No. 690, 86th Cong., 1st Sess. 3 (1959) (emphasis added).

74. Id. at 4; accord H.R. REp. No. 1800, 86th Cong., 2d Sess. 13 (1960).

75. S. REP. No. 690,86 th Cong., 1st Sess. 1 (1959). 
operations. ${ }^{76}$ Section 309 (f) represents a compromise between the two groups. ${ }^{77}$ Letters to Congress regarding the compromise proposal from FCC Chairman John Doerfer and FCBA President Leonard Marks both emphasize the narrowness of the statutory exception and the anticipated infrequency of its use. Chairman Doerfer described the provisions as applying only in "unusual circumstances," adding that "[i]n view of the findings necessary for invoking this section, it is anticipated that it will be rarely used."78 Mr. Marks described the provision as giving the Commission the power to issue teinporary authorizations not subject to the pre-grant procedure "in real and unusual emergencies," adding that the Commission's representations and the language of the provision "make clear [its] very limited apphication."79

Significantly, the FCBA explicitly expressed concern that a temporary authorization provision might be used as a "device for short-circuiting regular procedures." 80 In fact, the Association conditioned its support for the amendinents upon the understanding that section 309(f) would not be used to grant authority inerely because the proposed service was desirable or needed and would be delayed due to pre-grant protest procedures. ${ }^{81}$ Based on representations by the FCC, Marks explained to Congress, "the $[\mathrm{FCC}]$ intends to use the authority granted only in the most unusual and true emergency situations where there are compelling reasons requiring the conclusion that delay in Commission action itself will work an extraordinary hardship which would seriously prejudice the public interest." 82 It is thus obvious not only that Congress did not in-

76. See Conditional Grants, Pre-grant Procedure, Local Notice, Local Hearings, Payoffs, Suspension of Licenses, and Deceptive Practices in Broadcasting: Hearings Before a Subcomm. of the House Comm. on Interstate and Foreign Commerce, 86th Cong., 2d Sess. 134 (1960) (statement of Ernest Jennes, American Bar Association) [hereinafter Jennes Statement].

77. Letter from John C. Doerfer to Hon. John O. Pastore (July 22, 1959), reprinted in S. REP. No. 690, 86th Cong., ist Sess. 6 (1959) (section 309(d) in proposal was renumbered section 309 (f) in Act) [hereinafter Doerfer Letter].

78. Id. at 6.

79. Letter from Leonard H. Marks to Hon. John O. Pastore (July 22, 1959), reprinted in S. REP. No. 690, 86th Cong., 1st Sess. 9 (1959) [hereinafter Marks Letter]; see also Jennes Statement, supra note 76, at 135 (even though the Association was concerned that the pre-grant protest procedures might be circumvented by section 309(f), it endorsed the provision since "the [FCC] had to find that there are extraordinary circumstances requiring emergency operations in the public interest, a finding not too easy to make"). (emphasis added).

80. Marks Letter, supra note 79 , at 9.

81. The association has agreed to the provision oniy because it is satisfied that the letter and spirit of the language in which it is framed will preclude use of the authority granted for a preliminary authorization merely because the proposed service or operation could be found to be a needed and desirable one and the protection the Communications Act would normally afford to the rights of other parties would delay an authorization made in the Id. usual manner.

82. Id. 
tend for section 309(f) to permit transfers of ongoing broadcast operations before full review under section 309(b), but that the Commission itself did not intend to employ the special procedures of section 309(f) solely because a tender offer for a broadcast company had been made.

d. The 1982 version of section $309(f)$. The Commission defends its present application of section 309(f) to tender offers in part by referring to the 1982 amendment to that section. ${ }^{83}$ The amendment substitutes the word "temporary" for "emergency," extends the permissible STA period from 90 to 180 days, and removes the limit on the number of permissible extensions. Focusing on the insertion of "temporary" in lieu of "emergency," the Commission contends that the amendment broadens the section's reach. The Commission interprets the amendment as giving it authority to grant STA's in non-critical situations. ${ }^{84}$ In the FCC's view, to interpret the provision otlierwise would assume that "Congress, when amending the statute to delete the word 'emergency' in Section 309(f) made a virtually meaningless change." 85 The intended effect of the change, according to the FCC, is the removal of "a specific term of limitation," replaced with a mere description of time. Because "temporary" has always been in the language of section 309(f), its substitution for "emergency" results in no additional limitations.

One major flaw in the FCC's interpretation of the 1982 amendment is that Congress made clear that the only substantive change to section 309(f) intended by the 1982 amendment was a modification of the duration of STA grants. In fact, the Commission, which itself proposed the amendment, described it as part of a set of "teclinical . . . housekeeping amendments." 86 The Commission's description is especially significant in light of Congress' reliance on the FCC's representations. ${ }^{87}$ In its description of the changes to the STA provision, the House report made no mention of the substitution of "temporary" for "emergency." Instead, the House focused exclusively on increasing the permissible STA period to 180 days and removing the limit on the number of permissible extensions. ${ }^{88}$ The House conference report also concentrated solely on the

83. Communications Amendments Act of 1982, Pub. L. No. 97-259, 96 Stat. 1087, 1094. For text of section 309(f) as amended, see supra text accompanying note 25 .

84. Policy Statement, supra note 11 , at 1575 .

85. Id. at 1575 n.174 (quoting L.P. Media, 58 Rad. Reg. 2d (P \& F) 1527, 1530 (1985)).

86. Letter from FCC Chairman Mark S. Fowler to U.S. Senate (Sept. 23, 1981).

87. See A Bill to Amend the Communications Act of 1934 to Make Certain Technical Revisions Regarding the Administration of Such Act, and for Other Purposes: Hearing on H.R. 5008 Before the Subcomm. on Telecommunications, Consumer Protection, and Finance of the House Comm. on Energy and Commerce, 97th Cong., 1st Sess. 1 (1981) (legislative proposals incorporated in the amendment contain "primarily technical and housekeeping revisions of existing law").

88. H. REP. No. 751, 97th Cong., 2d Sess. 30 (1982). 
modified STA time spans when describing the purposes behind the amendment. ${ }^{89}$

Even if the FCC is correct that the change from "emergency" to "temporary" in the amendment was meant to broaden the scope of the section's applicability, tender offers would still fail to meet the provision's other requirements. The 1982 Amendment did not modify the section's limitation to "extraordimary circumstances" in which "operations" are necessary to avoid prejudice to the public interest.

The Commission, however, claims that tender offers satisfied even the original version of section 309(f). According to the FCC, even if the 1982 Amendment is purely technical and in no way expands the situations that qualify for STA's, the bifurcated procedure contained in the Policy Statement is nonetheless authorized "[b]ecause Section 309(f) was broad enough to encompass the grant of an STA in cases involving tender offers prior to the 1982 amendments." 90 The Coinmission is correct in that both before and after the 1982 Amendments, a section 309(f) STA was available to all applicants to which section 309(b)'s public comment period applied, including those seeking transfers of control. However, the fact that section 309(f) was available does not give validity to the categorical application of it to all tender offers by the Policy Statement. Both before and after the 1982 Amendments, a tender offer in and of itself does not constitute an "extraordinary circumstance" as Congress intended those words, and the mere transfer of control from a licensee to a trustee does not constitute "operations" that might be necessary to avoid prejudice to the public interest.

In view of the congressional focus solely on changes in the duration of the STA, the Commission's own representations to Congress, and the retention of both the "extraordinary circumstances" and the "operations" requirements, it is clear that even after the 1982 Amendment the Communications Act continues to require full section 309(b) review before permitting a transfer of ongoing broadcast operations. To conclude otherwise, as did the Commission in the Policy Statement, is contrary to the unambiguous intent of Congress. In fact, the Commission's conclusion effectively means that Congress, without so much as a recorded comment, authorized a return to the repealed post-grant protest procedures-in which the public could voice its concerns about an application only after the Commission has approved it.

Some corroboration of this interpretation may be gleaned from the comments of Representative John Dingell, Chairman of the House En-

89. H.R. CONF. ReP. No. 765, 97th Cong., 2d Sess. 36-37 (1982).

90. Policy Statement, supra note 11, at 1576; see supra note 59 and accompanying text. 
ergy and Commerce Committee, before the National Association of Broadcasters. He emphasized that section 309(f) "was not intended to be applied to mergers; it was designed to allow temporary broadcast operations in emergency situations such as the destruction of a broadcast facility by a hurricane." 91

The language and legislative history of the Communications Act unambiguousiy reveal that Congress did not intend a section 309(f) STA to be granted solely by virtue of a tender offer. For twenty-five years following the enactment of section 309(f) the FCC understood the clear intent of Congress. ${ }^{92}$ The Commission uniformly restricted section 309(f)'s application to circumstances coniplying with the terms of the provision-providing for temporary operations to start up or prevent discontinuance of services deened necessary to the public interest.

3. Commission Acknowledgement. The Conimission's own proceedings involving tender offers, as well as its rules implenienting section 309(f), demonstrate the Commission's acknowledgement that the requirements of section 309(f) are not categorically satisfied by tender offer applicants.

For over two decades following the enactment of section 309(f), the Commission consistently recognized that the provision, through its express language and legislative history, apphes only where temporary authority is necessary to commence broadcast operations in the public interest or to prevent their mterruption. ${ }^{93}$ In the past, the Commission

91. Dingell on Responsibility, Broadcasting, Oct. 14, 1985, at 44.

92. See Scalia, Judicial Deference to Administrative Interpretation of Law, 1989 DUKE L.J. 511, 518. Scalia confers a tempered deference to statutory interpretations made by government agencies:

[T] he existence of a 'long-standing, consistent agency interpretation' that dates to the original enactment of the statute may be relevant to the first step of Chevron-that is, it may be part of the evidence showing that the statute is in fact not ambiguous but has a clearly Id. defined meaning.

93. See, e.g., Entertainment Communications, Inc., 45 Rad. Reg. 2d (P \& F) 1685 (1979) (STA granted to operate from reloeated antenna site to permit continuous principal city service to Houston by sole classical music station serving city); Man Corp., 62 F.C.C.2d 260 (1977) (STA granted to avoid interruption of service of only local broadcast service in community); Washoe Empire, 58 F.C.C.2d 1372 (1976) (STA granted for construction of broadcast translator because equipment of only local TV station destroyed by fire); Ohio Educ. Television Network Comm'n, 37 Rad. Reg. 2d (P \& F) 1106 (1976) (STA granted to new applicant to maintain only educational TV service where existing licensee abruptly announced it was ceasing operations); Catholic Comm. for Refugees, 34 Rad. Reg. 2d (P \& F) 1555 (1975) (STA granted for initial radio service to Vietnamese refugees in refugee center awaiting resettlement in U.S.); Telemundo, Inc., 39 F.C.C.2d 522 (1973) (temporary authorization granted for new translator service to prevent loss of existing service); Green County Broadcasting Co., 24 Rad. Reg. 2d (P \& F) 143 (1972) (STA granted to new applicant to prevent loss of community's only aural broadcast service where existing licensee's license not renewed); NEO Broadcasting Co., 25 Rad. Reg. 2d (P \& F) 812 (1972) (STA granted to maintain only aural facility during negotiations for joint interim operations by competing applicants pending determination of 
thus refused to find the existence of "extraordinary circumstances" absent a showing that specific programming would not be available to the public without the grant of an STA. ${ }^{94}$

As support for its position that tender offers meet the requirements of section 309(f), the Policy Statement cites the only pre-1985 FCC proceeding in which section 309(f) was invoked in a transfer of control context, ${ }^{95}$ Gale Broadcasting Co. ${ }^{96}$ This case, however, does not provide precedent for the Commission's theory that the requirements of section 309(f) are met merely by an application to transfer control of a company holding a broadcast license. In Gale the requisite "extraordinary circumstances"-in the threat to continuation of operations and unavailability of the particular programming - existed independently of the transfer of control.

Gale involved an FCC approved assigninent of control of a station in accordance with section 309(b) procedures. The assigninent was set aside by the court of appeals as potentially contrary to the public interest. On remand, the Cominission determined that a question remained as to possible undue concentrations of control over the communications industry, a factor bearing on whether a transfer is in the public interest. The Commission, therefore, designated the issue for an evidentiary hearing. Pending this public interest determination, however, control of the broadcasting facility could not be returned to the former owner of the hicensed corporation because he had "become seriously disabled by a chronic and debilitating disease." 97 Without an STA authorizing the assignee to broadcast, the station, which supplied the only " 'fine arts' pro-

permanent licensee); Pacifica Found., 27 F.C.C.2d 64 (1971) (STA granted for FM station to operate from new site when previous site rendered unavailable by bombings); Nationwide Communications, Inc., 19 Rad. Reg. 2d (P \& F) 844 (1970) (STA granted to new translator applicants where no television station was available without translators and license of existing translator operator revoked); Voice of Reason, Inc., 17 F.C.C.2d 431 (1969) (STA granted to new applicant to return local AM outlet to the air after former licensee surrendered license); Regents of the U. of Idaho, 10 F.C.C.2d 690 (1967) (STA granted for VHF translator to provide new educational programming; delay would cause weather to prevent construction); Jellico Dev. Ass'n, 2 F.C.C.2d 221 (1965) (STA granted to restore the only local translator service which had terminated when former licensee failed to renew); Birmingham Broadcasting Corp., 3 Rad. Reg. 2d (P \& F) 252 (1964) (STA granted to new applicant to maintain the only local service where former permittee was denied license); Community Radio, Inc., 2 Rad. Reg. 2d (P \& F) 290 (1964) (STA granted to restore the only local service which had terminated when former licensee surrendered license); Seward Broadcasting Corp., 3 Rad. Reg. 2d (P \& F) 314 (1964) (STA granted when community's only station was destroyed by earthquake making immediate action imperative).

94. See, e.g., Indianapolis Broadcasting, Inc., 61 F.C.C.2d 48, 49 (1976) (STA denied, even though operations were to be interrupted, since party did not provide "any specific programming or service not otherwise available").

95. See Policy Statement, supra note 11, at 1573-74.

96. 15 Rad. Reg. 2d (P \& F) 337 (1969), reconsideration denied, 19 F.C.C.2d 623 (1969).

97. Id. at 342 . 
gramming" in the area, ${ }^{98}$ would not have been able to continue operations. 99 Although Gale demonstrates that section 309(f) may validly be employed in the context of a transfer of control, it lends no authority for the Commission's decision that all tender offers involving FCC licenses satisfy the requirements of section 309(f).

The Commission also relied on Telesis Corp. ${ }^{100}$ to justify its decision that applications for transfers of control meet the requirements for STA grants. The Commission's analogy to the special temporary authorization granted in the transfer context in that proceeding pursuant to section 309(c)(2)(G) for nonbroadcast operations, however, provides equally unconvincing support. ${ }^{101}$ The denial of temporary authorization in Telesis would have left the stations "unmanaged" and "in limbo."102 Additionally, section $309(\mathrm{c})(2)(\mathrm{G})$ is of questionable relevance because, untike section 309(f), it requires no showing either of extraordinary circumstances or that delay in the institution of operations would prejudice the public interest.

Only after the Commission tentatively decided to bypass the pregrant protest procedure of section 309(b) in tender offer situations pursuant to its Notice of Inquiry ${ }^{103}$ - the precursor to the Pohicy Statementare there FCC proceedings utilizing section 309(f) STA grants in such situations. In both One Two Corp. ${ }^{104}$ and L.P. Media, Inc. ${ }^{105}$ the Commission employed the two-step procedure of granting a trustee special temporary authority, followed by long form review of the tender offeror's application. These two proceedings, however, can hardly be considered justification or precedent for a decision that the Commission reached before it considered them. ${ }^{106}$

98. Id. at 338.

99. Upon reconsideration of the grant, the Commission again upheld that granting the STA was "the only course to permit continued service to the public during an expedited hearing." Gale, 19 F.C.C.2d at 624.

100. 68 F.C.C.2d 696 (1978).

101. Policy Statement, supra note 11 , at 1574 . Section $309(c)(2)(G)$ in its entirety provides that section 309 (b) does not apply to "a special temporary authorization for nonbroadcast operation not to exceed thirty days where no application for regular operation is contemplated to be filed or pending the filing of an application for such regular operation." 47 U.S.C. $\S 309(c)(2)(G)(1988)$.

102. Telesis, 68 F.C.C.2d at 700 .

103. See Notice of Inquiry, supra note 10, at \18 (adopted July 9, 1985; released August 20, 1985).

104. 58 Rad. Reg. 2d (P \& F) 924 (adopted July 12, 1985; released July 17, 1985).

105. 58 Rad. Reg. 2d (P \& F) 1527 (adopted August 26, 1985; released August 27, 1985).

106. It is interesting to note that in One Two Corp. the hostile tender offer was not itself the extraordinary circumstance requiring temporary authorization. The Commission emphasized the upcoming shareholders' meeting where management would propose its reorganization plan. This meeting was relied upon as the extraordinary circumstance since "a delay in [Commission] determination of this case beyond the August shareholders' meeting would deny [the target company] share- 
Nor can the Commission's own rules implementing section 309(f) be relied on to justify granting interim trusteeships for tender offers involving communication companies. ${ }^{107}$ To the contrary, the adoption of those regulations reinforces Congress' unambiguous intent to strictly himit section 309(f)'s applicability. Section 73.1635 of the rules promulgated by the Commission defines a special temporary authorization as "authority granted to a permittee or licensee to permit the operation of a broadcast facility for a hmited period at a specific variance from the terms of the station authorization [for example broadcasting from a different location] ...."108 The FCC thus initially recognized that section 309(f) is concerned with allowing broadcast operations to continue-not with the identity of the operators.

Section 73.3542 of the rules, ${ }^{109}$ also implementing section 309(f), demonstrates even more clearly that the Commission understood that tender offers alone do not satisfy the provision's requirements. Despite the 1982 amendment to section 309(f) substituting the term "temporary" for "emergency," this Commission rule limits temporary authority to "extraordmary circumstances requiring emergency operation to serve the public interest." 10 The examples of qualifying emergencies provided by the Commission all mvolve crisis situations such as threats to life, property, and national security. ${ }^{111}$ Although this regulation was meant to be merely indicative of situations that qualify for section 309(f) grants as opposed to an exhaustive list, ${ }^{112}$ it is clear that tender offers manifestly lack the requisite volatility.

The procedure endorsed by the Commission in the Policy Statement violates the mandates of the Communications Act. The language of section 309(f), its legislative history, and the Commission's own administration of the provision all reveal that Congress clearly and unambiguously did not intend the section's criteria to be satisfied merely by virtue of a tender offer.

holders the opportunity to consider the [tender offeror's] proposal at the same time as management's proposal." 58 Rad. Reg. 2d (P \& F) at 929.

107. Realizing that its regulations were not supportive of the new procedure, the Commission expressly disclaimed reliance on them. Policy Statement, supra note 11, at 1576 ("[W]e do not base our authority to utilize an STA upon any of our regulations; rather, it is predicated directly and exclusively upon Section 309 (f) of the Communications Act.").

108. 47 C.F.R. $\S 73.1635$ (a) (1989).

109. 47 C.F.R. $\S 73.3542$ (1989).

110. 47 C.F.R. $\S 73.3542$ (a) (emphasis added).

111. The example situations listed are "emergencies involving danger to life and property; a national emergency proclaimed by the President or the Congress of the U.S.A. and; the continuance of any war in which the United States is engaged, and where such action is necessary for the national defense or security or otherwise in furtherance of the war effort." Id.

112. The rule states that emergency situations "include" the enumerated crises. Id. 


\section{POLICY}

\section{A. The Statute's Public Interest Goal}

Not only is the Commission's procedure unlawful, but the policies underlying it contravene the Communications Act's charge to the FCC. The basic mandate of the FCC is to act in the public interest. ${ }^{113}$ The Commission's desire to furtler the free marketplace for transfer of control of companies holding broadcast licenses conflicts with its responsibility to ensure that transfers of control are in the public interest.

While complying with the procedural mandates of the Communications Act, the Commission must grant or deny applications for broadcast licenses, for renewals or modifications of those licenses, and for transfers of control involving companies lrolding sucl licenses, as the public interest, convenience and necessity dictate. Acting in the public interest is "[n]ot a standard that lends itself to application witlı exactitude." 114 The absence of a clear definition of the "public interest" does not, lowever, confer unlimited power on the FCC. The Supreme Court has "consistently held that the use of the words 'public interest' in a regulatory statute is not a broad license to promote the general public welfare. Rather, the words take meaning from the purposes of the regulatory legislation."115 The fundamental purpose of the Communications Act is to allocate and regulate the use of the airwaves. ${ }^{116}$ In light of this purpose, the public interest that the Commission is to further is the societal interest in receiving high-quality broadcast services from qualified licensees. ${ }^{117}$

The policy belind the FCC licensing procedures is protection of the public interest in broadcast services-not the protection of private economic interests. In the context of transfers of control involving broadcast licenses, therefore, the issues that the Commission lias traditionally addressed when making its public interest determinations include the fi-

113. Carroll Broadcasting Co. v. FCC, 258 F.2d 440, 443 (D.C. Cir. 1958).

114. FCC v RCA Communications, Inc., 346 U.S. 86, 90 (1953).

115. NAACP v. FPC, 425 U.S. 662,669 (1976).

116. FCC v. Sanders Bros., 309 U.S. 470, 474 (1940).

117. See One Two Corp., 58 Rad. Reg. 2d (P \& F) 924, 941 (1985) (Quello, Comm'r, dissenting); National Broadcasting Co. v. United States, 319 U.S. 190, 216 (1943); Sanders Bros., 309 U.S. at 475 ("An important element of public interest and convenience affecting the issue of a license is the ability of the licensee to render the best practicable service to the community reached by his broadcasts."). For a catalogue of the matters that the FCC routinely inquires into when making public interest determinations, see 3 Rad. Reg. Digest (P \& F) If 53.24. These matters include: the financial qualifications of the applicant, the applicant's character qualifications, violations of the Communications Act or FCC rules by the applicant, the degree of integration of ownership and management, the applicant's participation in civic activities, diversification of control of communications media, the applicant's sense of public service responsibility, its programming plans, and its efforts to ascertain community needs. Id. 
nancial qualifications of the transferee, ${ }^{118}$ the character qualifications of the transferee, ${ }^{119}$ and the transferee's responsiveness to the needs of the broadcast community. ${ }^{120}$ Although acting in the public interest will not necessarily further marketplace competitiveness, ${ }^{121}$ it is the Commission's directive.

\section{B. The Policy Statement's Goals}

The Commission determined that applying the traditional long form procedures of section 309 to tender offers results in protracted delay, unduly favors management, and conflicts with the policies underlying the Williams Act, all of which are said to disserve the public interest. ${ }^{122}$ The bifurcated procedure advocated in the Policy Statement was aimed at curing these "infirmities." 123 The policy objectives that the new procedure was to accomplish were accordingly: (1) to avoid unnecessary delay; ${ }^{124}(2)$ to promote strict governmental neutrality in the tender offer

118. See, e.g., MMM Holdings, Inc., 66 Rad. Reg. 2d (P \& F) 1593, 1597-1601 (1989) (applicant must demonstrate the availability of necessary funds with reasonable assurance in order to acquire cellular or television companies); The President and Directors of Georgetown College, 50 Rad. Reg. 2d (P \& F) 366 (1981) (Commission denied a reconsideration of transferring a license to applicant upon determining that applicant was financially qualified to acquire and operate a noncommercial educational radio station). See generally New Financial Qualifications Standard for Broadcast Assignment and Transfer Applicants, 49 Rad. Reg. 2d (P \& F) 1291, 1292 (1981) (applicants must show sufficient capital to consummate the transaction and to meet expenses for threc months).

119. The character of the applicant will be considered insofar as it involves violations of the Communications Act or the Commission's rules, instances of fraud or misrepresentation in programming, adjudicated instances of fraud before a governmental agency, criminal convictions involving fraud or dishonesty, and adjudicated instances of anticompetitive behavior. See Character Qualifications in Broadcast Licensing, 59 Rad. Reg. 2d (P \& F) 801 (1986). For reccnt examples of FCC inquiries into such matters in the transfer of control context, sec MMM Holdings, 66 Rad. Reg. at 1605 (potential antitrust violations); Gannett Co., 59 Rad. Reg. 2d (P \& F) 1054, 1055 (1986) (potential violations of multiple ownership rules); Acadian Television Corp., 51 Rad. Reg. 2d (P \& F) 743, 745 (1982) (same).

120. See, e.g., Metromedia Radio \& Television, Inc., 59 Rad. Reg. 2d (P \& F) 1196, 1202 (1985) (Commission assigned broadcast license to applicant dismissing the allegation that such a grant would not be in the public interest because of the possible increase in violent entertainment programming and a reduction in the amount of children's programming); Grinnell Communications Corp., 49 Rad. Reg. 2d (P \& F) 1520, 1523 (1981) (responsiveness to needs and interests of minorities in viewing area).

121. See Carroll Broadcasting Co. v. FCC, 258 F.2d 440, 443 (D.C. Cir. 1958) ("[C]ompetitive effects may under some sets of circumstances produce detriment to the public interest. When that happens the public interest controls."); Yankee Network v. FCC, 107 F.2d 212, 223 (D.C. Cir. 1939) (although Commission may appropriately be concerned with preserving competition in broadcasting, "it certainly does not follow therefrom that Congress intended the Commission to grant or deny an application in any case, other than in the interest of the public").

122. Policy Statement, supra note 11 , at 1562.

123. Id. at 1557 .

124. Id. at 1539. 
context; ${ }^{125}$ and (3) to accommodate other state and federal laws and policies concerning corporation governance. ${ }^{126}$ Although long form review has its faults, the Commission's characterization of its "infirmities" is misleading. In addition, the objectives sought may actually contravene the public interest.

1. Avoiding Delays. As indicated earlier, the long-form procedures of section 309 call for a thirty-day waiting period for public comment following public notice by the Commission of the filing of a license application. ${ }^{127}$ If petitions to deny the application are filed, then the applicant is allowed ten additional days to file an opposition. ${ }^{128}$ Reply to that opposition must be made withm five days after the time for filing oppositions has expired. ${ }^{129}$ An additional three days will be added to the opposition and reply filing periods if service is by mail. ${ }^{130}$ As the Coinmission summarized, this procedure leads to a "potential 51-day period before the pleading cycle ends. Intervention of weekends and holidays could extent [sic] the period even further. . . . If an evidentiary hearing were required [as would be the case if substantial questions of fact exist $^{131}$ ], the delay would be significantly longer." 132 The Commission concluded that these "unnecessary" delays disserve the public interest in the context of a tender offer. ${ }^{133}$

The Cominission, however, has the authority to reduce the deadlines for submission of responsive pleadings, as these time limits are not statutorily inposed. Recognition of the importance of public input on the licensing decision has lead the Coininission to conclude that expedition of the protest and response procedures would be "unwise .... [It] would impede the ability of interested parties to make their views known."134 The Coininission itself then implicitly accepts that delay in granting an application is a necessary element of protecting the public interest-not an unnecessary element to be avoided. ${ }^{135}$

\footnotetext{
125. Id. at 1540 .

126. Id.

127. 47 U.S.C. $\S 309$ (b) (1988); see supra note 22 and accompanying text.

128. 47 C.F.R. $\S 1.45$ (a) (1990).

129. 47 C.F.R. $\S 1.45(\mathrm{~b})(1990)$.

130. 47 C.F.R. $\$ 1.4(\mathrm{~h})(1990)$.

131. 47 U.S.C. \& 309(e) (1988).

132. One Two Corp., $58 \mathrm{Rad}$. Reg. 2d (P \& F) at 929 n.6.

133. Policy Statement, supra note 11, at $1539-40$.

134. Id. at 1562.

135. The decision not to abbreviate public comment periods due to the vital role of such input in licensing decisions is particularly significant in light of the tendency of the bifurcated procedure toward prejudgment. See infra notes $152-55$ and accompanying text. Because of the possibility of Cornmission bias, public input at step two of the review may be meaningless.
} 
The FCC supplied two examples to support its position that procedural delays harm the public interest, and thus that by avoiding these delays the Commission complies with its statutory duty of furthering the public interest. First, according to the Policy Statement these "unwarranted delay[s] unnecessarily burden the resources of private parties and the Commission."136 This allegation, although most likely true, does notling to support the FCC's position that this new procedure will further the public interest. In fact, the Commission's bifurcated procedure may unnecessarily burden the resources of private parties and the Commission to an even greater extent than the traditional long form review. Determining the trustee's qualifications and assessing the degree of the trustee's insulation from the offeror in step one of the procedure entails considerable burdens for proponents, opponents, and the Commission. Further, even under the new procedure the standard periods for public comment and petitions to deny will apply in step two when the tender offeror's license application is considered. Thus, the overall administrative burden on the Commission will likely be greater under the bifurcated procedure. The entire first step is an unnecessary expenditure of time and money in the event that a transfer of control to the tender offeror is not ultinately approved.

The Policy Statement's second justification for its position is that such delays can "deprive sliareholders of an effective choice in determining whether to tender their stock ...."137 Apparently, the FCC is referring to the possibility that incumbent management may take action during the FCC proceedings which effectively denies shareholders the option of tendering their stock. One Two Corp. involved a problem of that sort. The incumbent management was scheduled to present its own reorganization plan for the coinpany at an upcoming shareholder meeting. ${ }^{138}$ Due to the time constraints of long-form review, an FCC decision on the tender offeror's application would not be made prior to that nieeting. The Commission feared that sliareholders who accepted management's offer might do so only because the option to sell their stock to the tender offeror was not presented sinultaneously. The Coininission thus concluded that adninistrative delay might effectively deny shareholders the opportunity to consider the tender offeror's proposal. ${ }^{139}$

136. Policy Statement, supra note 11, at 1539.

137. Id.

138. One Two Corp., 58 Rad. Reg. 2d (P \& F) 924, 925 (1985).

139. "A delay in our determination of this case beyond the August shareholders' meeting would deny Multimedia's shareholders the opportunity to consider the Cooke proposal at the same time as management's proposal. Those shareholders who accept management's offer might never be able to consider Cooke's proposal." Id. at 929. 
There are two flaws in relying on this scenario as a basis for the theory that an alternative to long form procedures is necessary to further the public interest. First, the traditional procedure does not bar a tender offeror from informing stockholders of his intentions before the FCC approves his application. As the Commission phrased it, "[w]hile a person seeking control of a communications entity can initiate a tender offer for a licensee without our prior consent, ... [the Communications Act prohibits his acquiring] control through the purchase of the tendered stock until after the Commission grants approval of a license transfer application." 140 If the tender offeror chooses, he may apprise the stockholders of his plans and try to convince them of his proposal's merits. Even though his ultimate purchase of the stock may be delayed, if the stockholders favor his proposal they will not make corporate decisions that will bar its fruition.

More important than the fact that the traditional long-form procedures do not necessarily deprive shareholders of a choice, the Commission errs by focusing on the shareholders of the licensee to determine what is in the public interest. The Commission is too willing to equate private econormic interests with the "public interest." The FCC's desire to serve private shareholder interests should not be allowed to override its express statutory duty. The delays inherent in the Commission's admimistrative processes impose conditions on shareholders of communications entities that would otherwise not exist in the marketplace. ${ }^{141}$ The effects of these conditions should be of no concern to the FCC. As shown by the express terms of the Communications Act, Congress determined that the interests of private shareholders and their power to sell control of a broadcast company must be subordinated to and, if necessary, delayed by FCC examination of the larger public interest.

2. Promoting Neutrality. The second policy goal the Commission sought to achieve through the trusteeship procedure was the promotion of governmental neutrality in the context of tender offers. It is not in the public interest for an administrative process to be utilized as a shield by management or as a sword by the tender offeror. According to the FCC, delays inherent in the long form procedures "unduly favor the incumbent management of a licensee at the expense of a challenger in several respects." 142

140. Policy Statement, supra note 11, at 1557-58.

141. Id. at 1561 ("[T]hese delays effectively deprive shareholders of communications entities of options that would otherwise exist in the marketplace....").

142. Id. at 1558 . 
First, the Commission argues that traditional procedures make acceptance of tender offers unattractive to shareholders. Shareholders allegedly are faced with an indeterminate, but prolonged period during which their assets will be tied up if they accept the offer. In addition, the shareholders have no guarantee that the tender offeror will ultimately meet Commission approval and be able to purchase their stock. This portrayal of the unattractiveness of tendering shares is misleading. Although the tender offeror cannot purchase the shares before the Commission completes its review, the shareholder's assets are not tied up indefinitely. Nothing about Commission review bars the exercise of otherwise available rights under the Williams Act to withdraw tendered shares. ${ }^{143}$ Finally, that the shareholders of broadcast companies cannot be certain that a tender offeror will ultimately purchase their stock does not make tender offers unusually unattractive. Shareholders of any type of stock cannot be certain that the tender offeror will purchase all of their stock. ${ }^{144}$ Certainly the public interest does not demand affording coinmumications industry shareholders greater protections than those afforded to all others.

The Policy Statement's second illustration of how the use of longform procedures unduly favors incumbent management is that procedural delays may impede the tender offeror's effort. The offeror may not be able to consuminate the transaction prior to the time when the shareholders are permitted to withdraw their shares. ${ }^{145}$ As previously mentioned, ${ }^{146}$ the Williams Act gives tendering shareholders a statutory right of withdrawal sixty days after the commencement of the tender offer. ${ }^{147}$ If Commission review exceeds the sixty-day deadline, then the shareholders, having determined that it is not in their best interest to sell their stocks, inay decide to take advantage of their withdrawal rights. It is not the role of the Commission, however, to protect the tender offer of a challenger whose public interest qualifications have not even been examined.

As a final illustration of the claimed lack of neutrality in the use of long form procedures, the Commission refers to various efforts that in-

143. The Williams Act provides for two periods during which tendered shares can be withdrawn: during the first seven days of the tender offer and anytime after sixty days from the offer's commencement. 15 U.S.C. $\S 78 \mathrm{n}(\mathrm{d})(5)$ (1988).

144. In fact there are laws which anticipate over-acceptance by shareholders and focus on allocating between the tendering shareholders the number of stocks which are to be purchased. See 15 U.S.C. $\S 78 n(d)(6)$ (1988).

145. Policy Statement, supra note 11 , at 1559.

146. See supra note 38 .

147. In the Policy Statement, the Commission identifies the day of filing of a transfer application as the trigger for this sixty day period. Policy Statement, supra note 11 , at 1559 n. 108 . 
cumbent management can take to impede takeover bids while the tender offeror's application is being reviewed. ${ }^{148}$ The target company can

(1) repurchase its own securities; (2) announce dividend increases or stock splits; (3) issue additional shares of stock; (4) acquire other companies to produce an antitrust violation should the tender offer succeed; (5) arrange a defensive merger; (6) enter into restrictive loan agreeinents; [and] (7) institute hitigation challenging the tender offer. ${ }^{149}$

Although these options may be available to the target company's management-thereby giving it an advantage over the challenger-the Commission's presentation distorts the situation. The miplementation of these devices is not limited to the communications industry. In fact, the list was supphied by the SEC to demonstrate the various techniques employed by target companies generally to impede takeover attempts. ${ }^{150}$

Although the Commission presented a generally slanted picture of how the use of long form procedures unduly favors incumbent management, nrany of its contentions have merit. The tendency of such procedures to favor incumbent management, however, does not validate the Commission's goal of seeking to employ a procedure that favors neither inanagement nor challengers. There is no neutrality clause in the Commumications Act. In fact, the Act reflects a congressional intent to impose different burdens or standards on certain parties. ${ }^{151}$ No provision in the Act addresses the balance to be struck between management and challenger in a tender offer situation.

As a result, the validity of the Commission's neutrality goal depends on whether the limited favoring of management occasioned by the long form procedures serves the public interest. At the time a tender offer is made to the shareholders of a broadcast licensee, the Commission has already determined that incumbent management provides services that benefit the public interest. No such assessment of the tender offeror lias been completed. The Commission would not be protecting the public interest if it accorded the cliallenger's unassessed and uncertain impact on the public interest the same weight as incumbent management's established benefit to the public interest.

The bifurcated procedure the Commission has endorsed contravenes the FCC's ability to provide a fair assessment of the tender offeror's qualifications. When tlie Commission autlorizes an expedited transfer of ten-

148. Id. at 1560 .

149. Id. at 1560 n.111 (quoting Edgar v. Mite Corp., 457 U.S. 624,638 n.13 (1982)).

150. Edgar, 457 U.S. at 638 n.13.

151. For example, if more than one applicant for a single license meets the requirements of section 308, section 309(i) instructs the Commission to place "significant preferences" on applicants controlled by minorities. 47 U.S.C. $\S 309(\mathrm{i})(3)(\mathrm{A})(1988)$. 
dered stocks to a trustee, great potential exists for prejudgment and bias in favor of granting ultimate approval to the tender offeror. Once the target company has been placed in a trusteeship, the effect of Commission disapproval of the transfer application on the target, shareholders, and tender offeror himself could exert tremendous pressure on the Commission to approve the transfer of control. In fact, in none of the STA cases in which the trustee was able to consummate the tender offer has the FCC thereafter rejected the long form application of the tender offeror.

If the ultimate transfer is not approved by the FCC, a lengthy period may follow "during which control and the company's business plans may be uncertam ... impair[ing] the ability of the company to obtain financing, making it more difficult to operate the company." 152 These possible operational problems, which would affect not ouly the target company but also the remaining shareholders, may sway the Commission into approving a transfer that disserves the public interest when it assesses the merits of a transfer of control from the trustee to the tender offeror. In addition, disapproval by the Commission will require the trustee to dispose of the previously collected stock. Disapproval "may result in distress sale pricing, further exacerbating the problems of the target company" and remaiming shareholders. ${ }^{153}$ Finally, the Commission may feel pressure to approve the final transfer in order to avoid financial harm to the tender offeror, who bears the financial risk of any loss incurred when the trustee sells the tendered stock.

The D.C. Circuit has acknowledged the potential for prejudice at the final decisional stage created by interim grants of authority. In Community Broadcasting Co. v. F.C.C., the court vacated the FCC's grant of interim operating authority to one of two applicants competing for a license because "the grant of temporary authority . . . is pregnant with danger" of impairing the Commission's later decisionmaking. 154 Significant financial investment would have been at stake at the subsequent decisional stage, and the court found that "[o]rdinary human experience tells us that these factors have a force which cannot always be set aside by the triers no matter how sincere their effort or intent." 155 The risk that the Commission will be prejudiced when assessing the tender offeror

152. Policy Statement, supra note 11, at 1591 (quoting Notice of 1nquiry Comments submitted by CBS).

153. Stock prices may drop drastically due to the fire sale nature of the disposition. Id. at 1591 (citing Notice of Inquiry Comments submitted by CBS).

154. 274 F.2d 753, 758 (D.C. Cir. 1960).

155. Id. at 759. Later, in Consolidated Nine, Inc. v. FCC, the Court, in summarizing Community's holding, concluded that "[t]he tendency of this circumstance [prior expenditures] would be to prejudice the other applicant notwithstanding the Commission's good faith in trying to disregard the 
in the transfer proceeding demonstrates that the trusteeship procedure not only potentially lacks neutrahty, but also may disserve the public interest.

3. Accommodating Other Laws and Policies. The third policy objective the Commission intended to satisfy by adopting its new procedure for tender offer approval was to accommodate to the fullest extent possible state and federal laws and policies concerning corporations. More specifically, the Commission focused on the policies embodied in the Willians Act. ${ }^{156}$ One purpose of the Williams Act is to ensure that investors would have the ability to make informed decisions in response to tender offers. ${ }^{157}$ The Act includes filing and disclosure requirements, ${ }^{158}$ highest price guarantees, ${ }^{159}$ and antifraud provisions. ${ }^{160}$ As an additional protection afforded stockholders, the Act provides for two periods during which tendered shares can be witlidrawn: during the first seven days of the tender offer ${ }^{161}$ and any time after sixty days from the offer's commenceinent. 162

In its attempt to accommodate the policies behind the Williams Act, the Coinmission focuses on the latter time frame. The "60-day maximum," 163 as the Commission refers to it, represents a determination by Congress that an offeror who has not closed the transaction by that time should not be permitted to continue to lock up tendered stock. From this determination the Commission infers "a Congressional expectation that a tender offer would be conducted within this 60-day time period under ordinary circumstances." 164 To accommodate this "expectation,"

potential economic loss if the temporary operator were denied the final grant. . ." $403 \mathrm{~F} .2 \mathrm{~d} 585$, 589 (D.C. Cir. 1968).

156. The Williams Act, Pub. L. No. 90-439, 82 Stat. 454 (1968) (codified as amended at 15 U.S.C. $\S \S 78 \mathrm{~m}(\mathrm{~d})$-(e), 78n(d)-(f) (1988)).

157. The Act "is designed solely to require full and fair disclosure for the benefit of investors." 113 CONG. REC. 24664 (1967) (Statement of Sen. Williams). Achieving governmental neutrality was not the object of the Act, but is a necessary characteristic of legislation with the purpose of protecting shareholder interests. Piper v. Chris-Craft Indus., 430 U.S. 1, 30 (1977). For discussion of neutrality as an FCC policy objective, see supra notes 142-155 and accompanying text.

158. Upon commencement of a tender offer, the offeror is required to provide information regarding the offer to shareholders, the SEC, and the target company. 15 U.S.C. $\S 78 n(d)(1)$ (1988).

159. Shareholders need not hold out for fear that they will be financially disadvantaged if they tender their stock early. The offeror is required by statute to purchase all tender shares at the same price. If the purchase price increases during the offer, stockholder's who already tendered shares receive the benefit of that increase. 15 U.S.C. $\S 78 \mathrm{n}(\mathrm{d})(7)(1988)$.

160. 15 U.S.C. $\$ 78 \mathrm{n}(\mathrm{e})(1988)$.

161. 15 U.S.C. $\$ 78 \mathrm{n}(\mathrm{d})(5)$ (1988). The SEC, through a regulation, has extended the initial period to 15 business days. 17 C.F.R. $\S 240.14 d-7$ (a)-(1) (1989).

162. 15 U.S.C. $\S 78 \mathrm{n}(\mathrm{d})(5)$ (1988).

163. Policy Statement, supra note 11, at 1556.

164. Id. 
the Commission's bifurcated procedure is designed to permit consummation of the tender offers within sixty days.

The FCC has no legal mandate to enforce any statute other than the Communications Act. Accordingly, the Commission cannot abrogate its statutory duties in the name of comity. The Commission may, however, consider all relevant factors in determining what best serves the public interest, including the federal policy underlying the Williams Act. ${ }^{165}$ Whether the policies of the Williams Act should ultimately be relied on by the Commission in altering its tender offer procedures depends largely upon the similarity between the duties and roles of the SEC and the FCC and the similarity between the goals sought by the Williams Act and the Communications Act. 166

The SEC's mandate is the consideration of shareholder and investor interests, whereas the FCC is concerned with the listening and viewing public. Interests of shareholders and investors and interests of the public at large may conflict. The objective of the SEC under the Williams Act is to implement the policy of full disclosure, enabling shareholders and investors to make informed decisions. ${ }^{167}$ Unlike the FCC, the SEC is not concerned with the substantive impact of the transaction on the operations of the target company or on the welfare of non-investors. ${ }^{168}$ With such entirely different duties and objectives, the FCC and the SEC understandably have different types and lengths of regulatory review. If the FCC is to protect the public interest in high-quality broadcast service from a qualified broadcaster, it is inappropriate for the Commission to gauge its tender offer procedures by the standards of the SEC.

\section{ConClusion}

The Commission abrogated its statutory mandate in adopting the Policy Statement's bifurcated procedure for tender offer applications.

165. See"La Rose v. F.C.C., 494 F.2d 1145, 1147 n.2 (D.C. Cir. 1974) ("Administrative agencies have been required to consider other federal policies not unique to their particular area of administrative expertise, when fulfilling their mandate to assure that their regulatees operate in the public interest."); Storer Communications, Inc. v. FCC, 763 F.2d 436, 443 (D.C. Cir. 1985) (Commission must implement Communications Act as consistently as possible with the objectives of securities laws).

166. Cf. McLean Trucking Co. v. United States, 321 U.S. 67, 83-85 (1944). Though they both applied to the same entity, the railroad legislation was enacted to further different goals in a different manner than the anti-trust laws; the railroad legislation achieved the public interest of an "adequate, efficient, and economical system of transportation through close supervision of business operations and practices rather than through heavy reliance on the enforcement of free competition," id. at 83 , so the ICC was instructed not to measure proposals by the standards of antitrust laws.

167. See Piper v. Chris-Craft Industries, Inc., 430 U.S. 1, 32 (1977); Schreiber v. Burlington N., Inc., 472 U.S. 1, 8 (1985).

168. See Schreiber, 472 U.S. at 11. 
The language of section 309(f), its legislative history, and the Commission's own administration of the provision reveal that tender offers do not categorically satisfy the criteria of section 309(f). The illegal procedure cannot be staunchly defended even on policy grounds. The policy objectives that the Commission sought to achieve by employing a section 309(f) STA in the context of tender offer applications are arguably invalid themselves. In its effort to expose the broadcast industry to aspects of the free market for corporate control, the Commission neglected its congressionally prescribed mission to serve the public interest-not shareholder and market place interests. In order for the bifurcated procedure adopted in the Policy Statement to be legally applied categorically to all tender offers, congressional action is necessary. Congress will need to amend the Communications Act's license approval procedures and perhaps even the Commission's public interest mandate.

Jennifer L. Gimer 
